\title{
Uso de Infliximabe em Vasculite Reumatóide
}

\section{Infliximabe use in Rheumatoid Vasculitis}

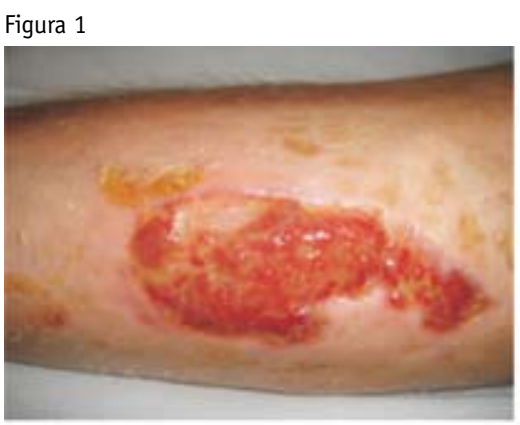

Figura 2

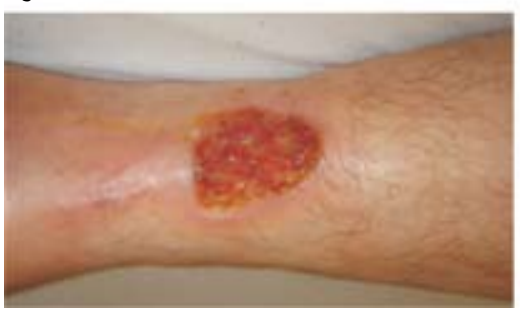

Figura 3

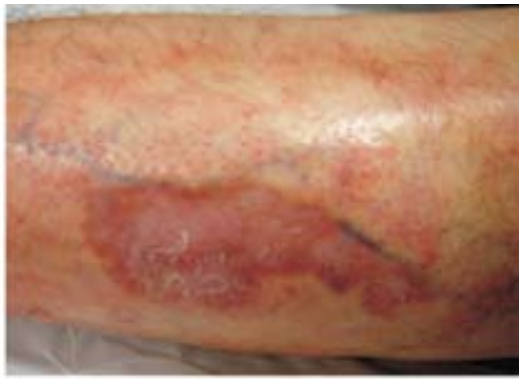

Figura 4

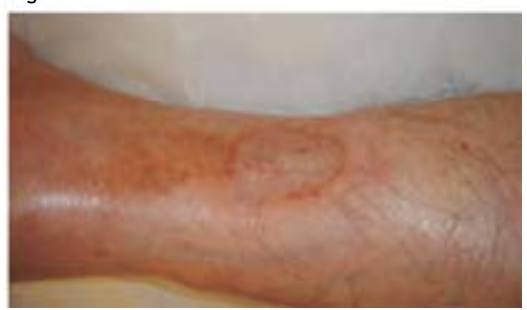

Paciente do sexo feminino, 47 anos, com artrite reumatóide (critérios da ACR, 1987) desde os 27 anos de idade. Há 3 anos, vinha cursando com lesões ulceradas em perna esquerda (Figura 1: face lateral; Figura 2: face medial), com boa perfusão periférica, sem déficit neurológico local ou presença de varizes). Realizaram-se os seguintes exames laboratoriais: fator reumatóide negativo, marcadores de atividade inflamatória de fase aguda elevados, porém com níveis de complemento sérico e hemograma sempre dentro da normalidade. As lesões apresentavam refratariedade a diversas drogas modificadoras da doença, em dose plena (ciclosporina, clorambucil, D-penicilamina, sulfassalazina e metotrexato), bem como pulsoterapia com metilprednisolona $500 \mathrm{mg}$ por $3 \mathrm{~s}$ dias (duas ocasiões) e ciclofosfamida mensal ( $1 \mathrm{~g} / \mathrm{m}^{2}$ superfície corpórea, total de 14 vezes). Há 1 ano, optou-se por iniciar terapia com infliximabe $(3 \mathrm{~m} / \mathrm{kg})$ associada a metotrexato $12,5 \mathrm{mg} / \mathrm{semana}$ e prednisona $5 \mathrm{mg} /$ dia oral. A partir da quarta dose, aplicação bimestral; na sexta dose, aumentou-se infliximabe para $5 \mathrm{mg} / \mathrm{kg}$, com melhora parcial das lesões. A partir da nona dose, evoluiu com cicatrização completa das lesões (Figuras 3 e 4). Atualmente, estável com uso de metotrexato e prednisona nas doses mencionadas anteriormente.

Caso encaminhado por Samuel K. Shinjo (médico-residente) e Dra. Jussara A. L. Kochen (médica-assistente) do Serviço de Reumatologia do Hospital das Clínicas da Faculdade de Medicina da Universidade de São Paulo, e-mail: jussara.kochen@gmail.com 